\title{
Impact of the white pine weevil (Pissodes strobi Peck) on Norway spruce plantations (Picea abies [L.] Karst.] Part 1: Productivity and lumber quality ${ }^{1}$
}

\author{
by Gaëtan Daoust² ${ }^{2}$ and Marie-Josée Mottet ${ }^{3}$
}

\begin{abstract}
A study to assess the effects that major deformations in merchantable stems of Norway spruce (Picea abies [L.] Karst.), caused by the white pine weevil (Pissodes strobi [Peck]), have on lumber productivity and quality was performed on logs obtained from a second commercial thinning operation in three weevil-affected plantations. Deformed stems were found to be $6.3 \%$ shorter than non-deformed stems and their lumber characteristics, i.e., merchantable volume, number of board feet and lumber monetary value, were $14.7 \%, 20.6 \%$ and $23.7 \%$ lower, respectively. However, when the respective proportions of deformed and non-deformed stems were analyzed for a given plantation over the time horizon of a complete rotation, these shortfalls almost disappeared, with a loss of less than $3 \%$ being noted for total merchantable volume. The presence/absence of major deformations had no effect on visual grading of the lumber, which takes defects such as wane, knots and compression wood into account. For two of the three sites studied, almost $75 \%$ of the lumber was graded as Select Structural, No. 1 or No. 2. The plantation site and its characteristics (spacing and level of thinning) were found to have a more significant effect than deformations on productivity, lumber quality and monetary value. Furthermore, using the same methodology, one of the Norway spruce sites was compared with a white spruce (Picea glauca [Moench] Voss) plantation containing trees of similar quality and height, but with no weevil problems. The Norway spruce stems, including those with deformations, were found to yield higher merchantable and usable log volumes, a larger number of board feet and a higher monetary value than white spruce. On average, for the diameter at breast height values tested - 14 to $23 \mathrm{~cm}$ - the monetary value of the lumber was $26 \%$ higher for Norway spruce. These findings are largely attributable to the less pronounced taper of Norway spruce. In conclusion, in spite of weevil attacks and their negative impact, Norway spruce trees growing on sites of moderate to very good quality maintain lumber potential, in terms of both quantity and quality, for second thinning logs. The negative impact should gradually decrease at the time of next thinnings and final harvest.
\end{abstract}

Key words: white pine weevil, Pissodes strobi (Peck), Norway spruce, Picea abies (L.) Karst., wood quality, plantation, productivity

\section{RÉSUMÉ}

L'impact des déformations majeures causées par le charançon du pin blanc (Pissodes strobi [Peck]) aux tiges commerciales d'épinette de Norvège (Picea abies [L.] Karst.) sur la productivité et la qualité des sciages a été évalué à partir de billes récoltées lors de secondes éclaircies commerciales dans trois plantations affectées par l'insecte. Comparativement aux tiges non déformées, les résultats ont démontré que les tiges déformées étaient moins hautes de $6,3 \%$ et avaient un volume marchand, un nombre de pmp et une valeur monétaire des sciages inférieurs de 14,7, 20,6 et de 23,7 \%, respectivement. Toutefois, ces pertes deviennent presque négligeables et inférieures à $3 \%$ au niveau de la production en volume marchand total de la plantation puisque les tiges déformées représentent une partie seulement de l'ensemble des tiges présentes ainsi qu'une faible proportion du volume total récolté sur un horizon correspondant à une rotation complète. La présence ou non de déformations majeures n'a pas eu d'effet sur la classification visuelle des sciages qui tient compte de défauts comme la flache, les nœuds ou le bois de compression. Pour deux des trois sites, près de $75 \%$ des sciages ont été classifiés dans la catégorie regroupant Structure choisie, $\mathrm{N}^{\circ} 1$ et $\mathrm{N}^{\mathrm{o}}$ 2. Le site et ses caractéristiques (espacement et régime d'éclaircie) ont eu des effets plus importants que les déformations sur la productivité, la qualité et la valeur monétaire des sciages. Sur un des trois sites, les résultats ont été comparés à ceux obtenus dans les mêmes conditions pour des tiges provenant d'une plantation d'épinettes blanches (Picea glauca [Moench] Voss) de qualité comparable et de hauteur équivalente, mais non affectée par le charançon. Il en est ressorti que le rendement en volume et la qualité des sciages sont supérieurs chez l'épinette de Norvège regroupant à la fois les tiges déformées ou non par les attaques du charançon. En moyenne, pour les diamètres à hauteur de poitrine testés, soit de 14 à $23 \mathrm{~cm}$, l'épinette de Norvège offrait une valeur monétaire des sciages supérieure de $26 \%$ par rapport à l'épinette blanche. Le défilement moins prononcé chez l'épinette de Norvège expliquerait en majeure partie les résultats obtenus. En conclusion, malgré les attaques du charançon du pin blanc et leur impact négatif, l'épinette de Norvège, plantée sur des sites correspondant à des indices de qualité de station moyenne à très bonne, maintient un potentiel de productivité important tant en quantité qu'en qualité pour les bois prélevés en deuxième éclaircie. L’impact négatif devrait s’amenuiser graduellement au cours des prochaines éclaircies et lors de la récolte finale.

Mots clés : charançon du pin blanc, Pissodes strobi (Peck), épinette de Norvège, Picea abies (L.) Karst., qualité du bois, plantation, productivité

\footnotetext{
${ }^{1}$ Translation of "Impact du charançon du pin blanc (Pissodes strobi Peck) dans les plantations d'épinettes de Norvège (Picea abies [L.] Karst.) Partie 1 : Productivité et qualité des sciages," which appeared in the July/August 2006 issue of The Forestry Chronicle.

${ }^{2}$ Natural Resources Canada, Canadian Forest Service, Laurentian Forestry Centre, 1055 du P.E.P.S., P.O. Box 10380, Stn. Sainte-Foy, Québec, Quebec G1V 4C7. All correspondence should be addressed to the first author. E-mail: gaetan.daoust@rncan.gc.ca

${ }^{3}$ Ministère des Ressources naturelles et de la Faune du Québec, Direction de la recherche forestière, 2700, rue Einstein, Québec (Quebec) G1P 3W8
} 


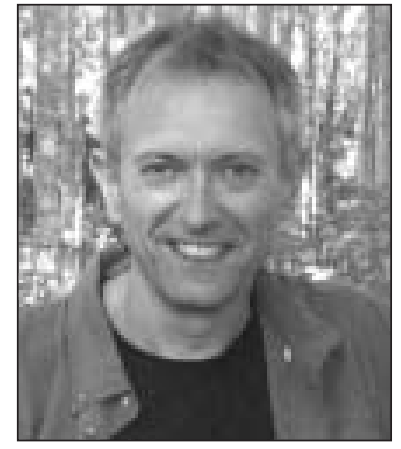

Gaëtan Daoust

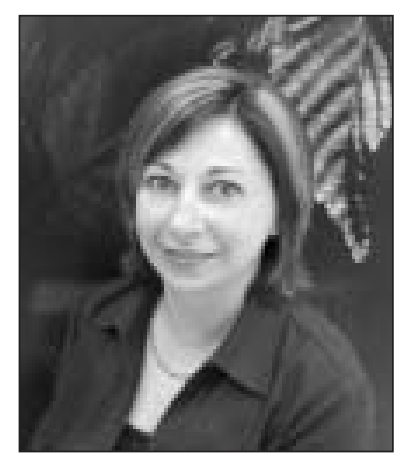

Marie-Josée Mottet

\section{Introduction}

Norway spruce (Picea abies [L.] Karst.), with its crown characterized by more or less dangling branches, is much more than an interesting species for arboriculture. In fact, this species is also used in several eastern Canadian provinces for the production of lumber and pulp and paper. In Quebec, the oldest commercial plantations go back to the 1920s, and the great majority of them were harvested recently. From 1965 to 1995, over 200 million seedlings of this species were planted in Quebec (Cornellier 1995). Its popularity continued to increase up until the end of the 1980s, when up to 18 million plants per year were being planted in Quebec, almost two thirds of which were in private forests. Norway spruce, one of the most productive coniferous plantation trees, can yield 6.5 $\mathrm{m}^{3} \mathrm{ha}^{-1} \mathrm{yr}^{-1}$ on medium-quality sites (Thiffault et al. 2003) and even surpass $10 \mathrm{~m}^{3} \mathrm{ha}^{-1} \mathrm{yr}^{-1}$ on the most fertile sites, depending on certain management scenarios (Prégent 1998).

The keen interest in reforestation of this species in Quebec rapidly diminished when regional forestry advisors were confronted with the spectacular damage caused to young plantations by the white pine weevil (Pissodes strobi [Peck]) and with the negative pressure by private owners following these findings. The white pine weevil is among the insect pests that cause the most damage to Norway spruce plantations in southern Quebec. The plantations most affected are located on sites that are not recommended for this species, where drainage is slow and deficient, and the granulometry of the soil is fine (Archambault et al. 1993). The most common defects found in spruce plantations affected by the weevil following the death of the leader are the formation of forks, curves, bayonets or multiple stems (Alfaro 1989). However, this insect does not cause the death of the tree. This loss of interest in the species for reforestation is not a recent phenomenon. At the beginning of the 1970s, Baldwin et al. (1973) mentioned that the extent of the damage was so significant that the planting of Norway spruce had been practically given up in certain northeastern regions of North America. At the beginning of the 1990s, the same phenomenon occurred in Quebec. Several regions greatly affected by the weevil, the Eastern Townships, Central Quebec and Outaouais in particular, stopped using this species for reforestation. At the beginning of the 21st century, the number of Norway spruce seedlings being used for reforestation in Quebec, on private and public land, was less than 2 million (Bernier et al. 2003).

Despite comparable susceptibility, it seems that Norway spruce is able to overcome the deformations caused by the weevil more easily than white pine (Pinus strobus L.) (Ashman 1962). With time and radial growth, damage to trunks becomes less visible and sometimes disappears completely (de Groot et al. 2005). Despite the fact that young plantations affected by the weevil seem to be in such bad condition that one wonders whether they will produce usable wood, several old plantations of Norway spruce nevertheless present a quite reasonable overall appearance (Holst 1955). Following the assessment of a dozen plantations or so over the age of 40 in southern Quebec, MacArthur (1964) concluded that the fear of a disaster caused by weevil attacks was not justified because Norway spruce recuperates rapidly and suffers little loss in the production of wood destined for pulp and paper. However, he pointed out that the most serious effect of damage caused by the weevil would be the significant deterioration in the quality of logs destined for lumber. However, after thinning, several of these plantations presented a very nice appearance with a large proportion of wood suitable for lumber. One of these plantations, the Smith plantation, located in Lingwick (Quebec), produced a total of $700 \mathrm{~m}^{3} \mathrm{ha}^{-1}$ at 70 years and a lumber yield that surpassed estimates at the time of final cutting in 1991 (S. Gendron, Domtar Inc., personal communication). The appearance of the plantations studied by MacArthur had so greatly improved that following commercial thinning in the 1970s and 1980s, over half of them were used as seed collection stands by the ministère de l'Énergie et des Ressources du Québec. Some were recommended as seed sources of good genetic quality for reforestation in southern Quebec (CAGAFQ 1983).

Over the years, in order to counter this significant decrease in the use of the species in Quebec, which was deemed unjustified by several foresters, efforts were made to demonstrate that the impact of the weevil on the productivity of plantations was not as serious as the state of young plantations could lead one to believe. According to Daoust (1996), the impact of the weevil on the yield and quality of stems for lumber is low when Norway spruce is planted on medium to good quality sites and when the most-affected stems are harvested during the first thinning. Following the attacks, the species is able to correct the deformations. During the examination of two Norway spruce plantations under 30 years of age, Boulet et al. (1997) estimated that economic losses at the time of sawing would be less than the $25 \%$ estimated for white pine in natural stands (Brace 1971), that the damage observed in young plantations would greatly diminish over time, and that economic losses at the time of final harvesting would be negligible.

While information regarding the impact of the weevil on white pine is relatively abundant, no detailed study is available for other host species (de Groot et al. 2005). In the context of the Quebec forest industry, most of the wood produced on plantations is first used in the lumber industry, and it is mainly the chips produced during processing that are destined for the pulp and paper industry. In order to reassure forestry advisors and private owners, it is essential to conduct precise assessments of weevil impact on the productivity and quality of Norway spruce lumber.

In this study, we examined the impact of the deformations caused by the white pine weevil on Norway spruce harvested during a second thinning in three plantations established in Quebec that were severely affected by the insect. More 
Table 1. Site, plantation year, plantation spacing, site quality index, percentage of green crown, pruning height, number of stems harvested per grade category, and total number of stems harvested.

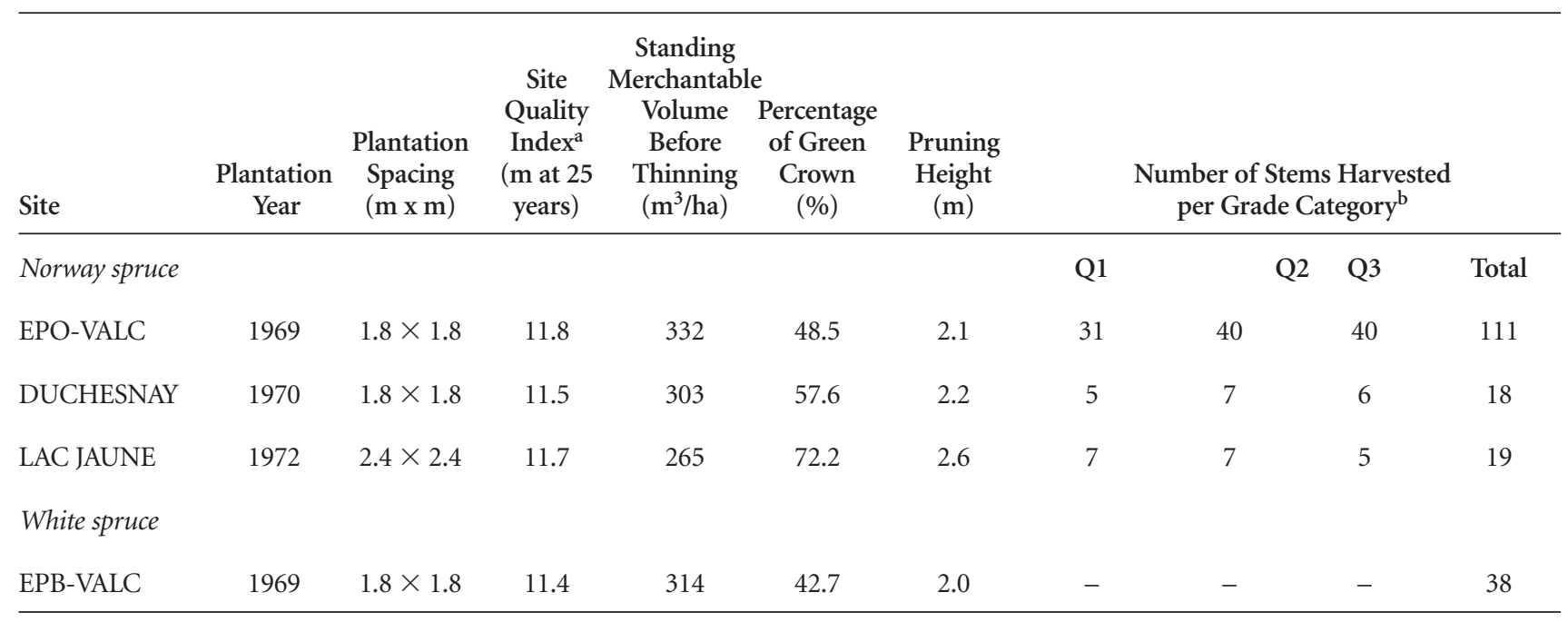

aBased on Bolghari and Bertrand (1984).

bWhite spruce and three grade categories of Norway spruce were considered: Q1= Stem without major deformations; Q2 = Stem with only one major deformation on the merchantable part $(>9 \mathrm{~cm})$; Q3 $=$ Stem with more than one major deformation on the merchantable part.

specifically, the objectives of the study were to assess the impact of the weevil (1) on the yield in merchantable volume and usable volume, (2) on the quantity of lumber, its classification in accordance with the rules of the National Lumber Grades Authority (NLGA 1996) and its relative market value, and (3) to compare the results obtained for one of the plantations with a white spruce plantation (Picea glauca [Moench] Voss) established on the same site with similar characteristics and a comparable silvicultural system.

\section{Materials and Methods Materials}

The Norway spruce stems used in this study originate from three experimental plantations, two of which are provenance trials of European origin (Valcartier and Lac Jaune), while the third (Duchesnay) is a plantation with superior-height seedlings of Proulx origin. The Valcartier (EPO-VALC) plantation contains 22 central European sources and it was established by the Canadian Forest Service at the Valcartier forest site in 1969 (Lat. $46^{\circ} 57^{\prime} \mathrm{N}$, Long. $71^{\circ} 29^{\prime} \mathrm{W}$ ). The Lac Jaune plantation (LAC JAUNE), primarily composed of French sources, was established in 1970 by the Forest Research Branch of the Ministère des Ressources naturelles et de la Faune du Québec at the Duchesnay forest site (Lat. $46^{\circ} 52^{\prime} \mathrm{N}$, Long. $71^{\circ} 40^{\prime} \mathrm{W}$ ). The Duchesnay plantation (DUCHESNAY) was established in 1972 also at the Duchesnay forest site. The seedlings of this plantation originated from a mass selection carried out in a three-year-old production planting bed at the Grandes-Piles nursery in Quebec. The Proulx source area, a plantation from 1925 established in Grandes-Piles, is considered an adapted local source area and is recommended as a source of seeds for reforestation in southern Quebec (CAGAFQ 1983). These three Norway spruce plantations were used for the study because they represent plantations of similar age in which the white pine weevil has caused significant damage. The five-year readings carried out in the follow-up of these three plantations demonstrated the presence of weevil attacks in the first reading, five years after planting. Afterwards, the annual ratio of attacks progressed to reach levels varying between $25 \%$ and $30 \%$, whereas for LAC JAUNE the ratios were $46 \%$ and $47 \%$ in 1986 and 1991, respectively. A first low thinning was carried out in these three plantations approximately 20 years after their establishment, which allowed the stems most affected by the weevil to be removed. The silvicultural characteristics of each plantation are shown in Table 1.

The white spruce stems originate from a provenance/ progeny test established at the Valcartier (EPB-VALC) forest station in 1969, which displayed remarkable growth, and where the progenies originated from Petawawa, Ontario. Several superior progenies from this test were retained for the tree improvement program of this species in Quebec (Beaulieu 1996). The EPO-VALC and EPB-VALC plantations underwent a similar silvicultural treatment (clearing, fertilization and pruning) at the same age, and the site quality indicators are comparable (Table 1). White spruce was chosen because it has the same edaphic and silvicultural requirements and it is primarily used in plantations in southern Quebec.

For the four plantations, the stems used in this study originate from trees previously marked for harvesting at the time of a second low thinning. For tests of Norway spruce provenance and of white spruce provenance-progeny, the stems were chosen from provenances or progenies that had displayed above-average performance in the test. The stems were chosen randomly in accordance with a diameter at breast height (DBH) gradient covering from 14 to $23 \mathrm{~cm}$ and based on whether they belonged, in the case of the Norway spruce, to one of the three grade categories attributed to the absence or presence of one or more major deformations caused by the weevil, irrespective of minor deformations that may be present (Figs. 1 and 2). Thus, grade category 1 (Q1) was allocated to stems displaying no major deformations, grade category $2(\mathrm{Q} 2)$ was allocated to stems showing a major 


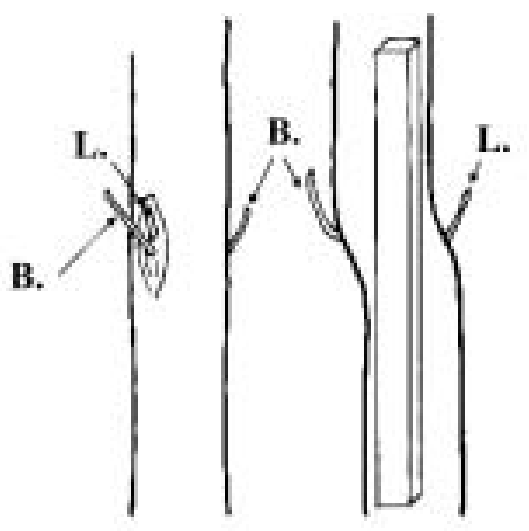

Minor deformations

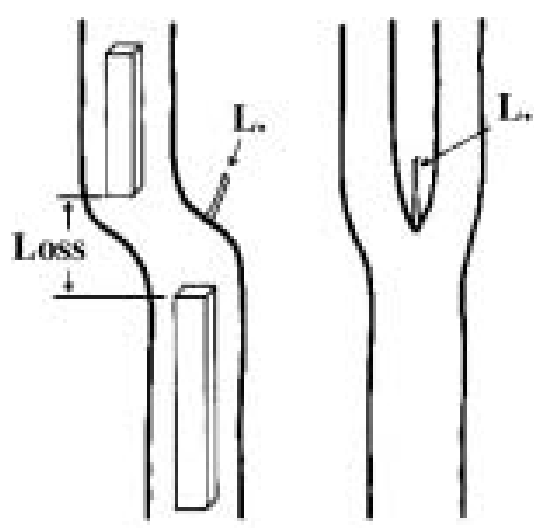

Major deformations

Fig. 1. Minor and major deformations on Norway spruce stems after attacks by white pine weevils. When the leader (L.) is killed, the lateral branches of the nearest whorl below it will turn upward and assume leadership. Usually, a single branch dominates and deformation ensues. The competing branches (B.) can be recognized by their steep angles. Adapted from Alfaro (1989).

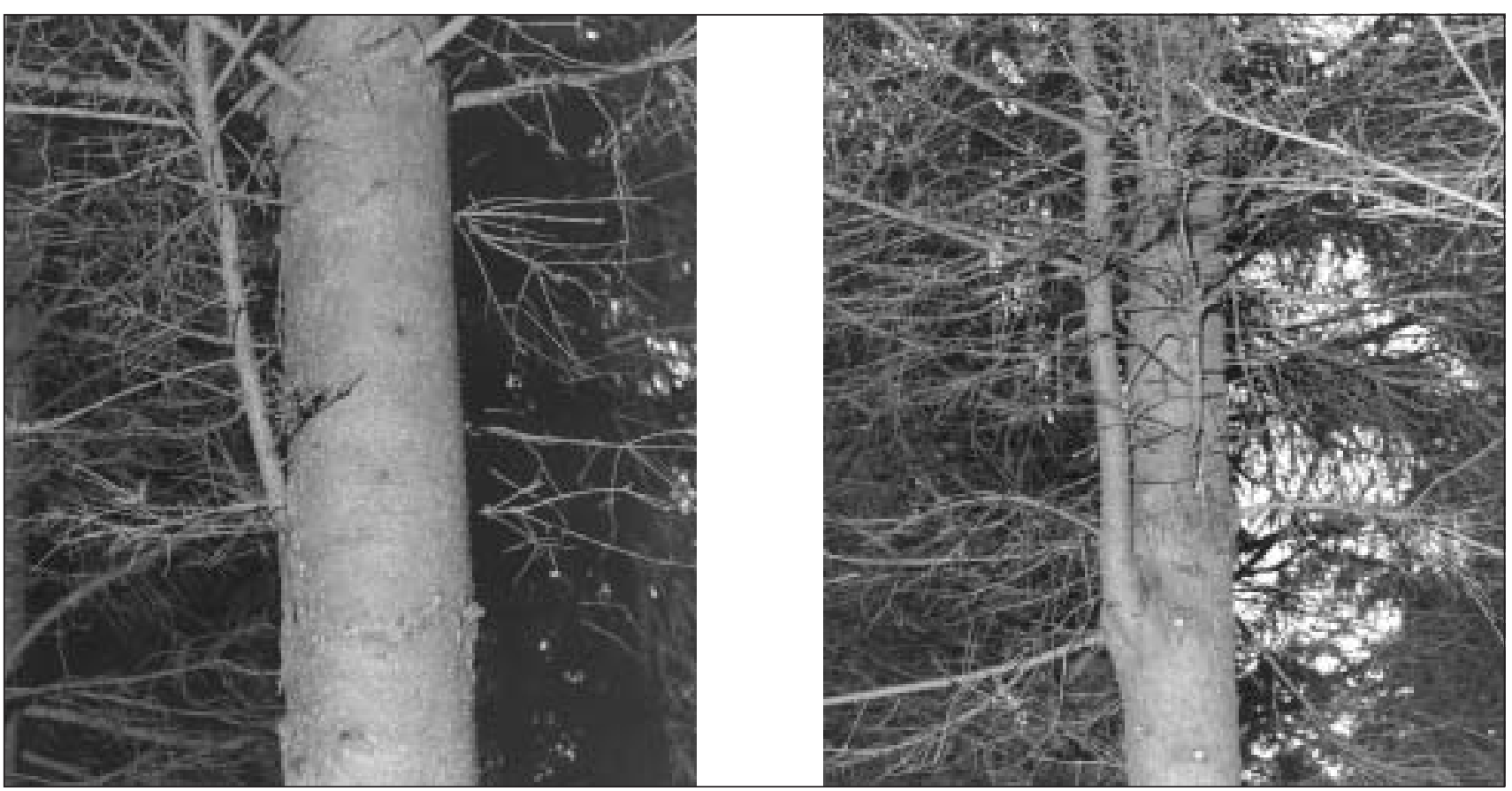

Fig. 2. Competing branches and minor deformations caused by white pine weevil attacks.

deformation only in their commercial section $(>9 \mathrm{~cm})$, and grade category $3(\mathrm{Q} 3)$ represented stems with more than one major deformation. For white spruce, no grade category was allocated because this species is not very susceptible to weevil attacks and major deformations caused by this insect or other causes were very rare in the plantation.

\section{Methods}

The 186 stems chosen were numbered, cut, delimbed, and skidded lengthwise. At the cross-cutting site, the $\mathrm{DBH}$ and the total length (TL) and merchantable length (ML) $(>9 \mathrm{~cm})$ of the stems were measured. Each stem was sawn into 8-foot (254-cm) logs. For Q2 and Q3 stems, the logs were sawn in such a way as to avoid major deformations that could have resulted in the rejection of the log upon loading or at the sawmill. Each log was numbered according to its position on the stem, and its diameter inside the bark at the thick and thin ends was measured. For each of the stems, two to five logs were produced during cross-cutting. The logs were sent to the school sawmill at l'École de foresterie et de technologie du bois de Duchesnay in Quebec.

At the school sawmill, each log was cut in order to produce 2-in. thick (51 mm) and 6-in. (152 mm), 4-in. (102 mm) and 3 -in. $(76 \mathrm{~mm})$ wide lumber. Wherever possible, 1 -in. $(25 \mathrm{~mm})$ 
thick boards of various widths were sawn. All of the lumber drawn from one log was numbered according to origin, stem and log. Two-inch lumber was dried to reach a moisture content of $15 \%$. A drying schedule particular to Norway spruce (Pratt and Turner 1986) was used and customized in accordance with the juvenile characteristics of the wood and the initial moisture content, which varied between $25 \%$ and $45 \%$. After drying, the lumber was dressed and categorized in accordance with NLGA grading rules for dimension lumber. The five categories are Select Structural, No. 1, No. 2, No. 3 and Economy. One-inch lumber was categorized in accordance with NLGA rules, undried and unplaned. Four categories were used: No. 1, No. 2, No. 3 and Economy. Each piece of lumber was assigned a monetary value in accordance with its classification, dimension and the average price of wood on the 2001 Montreal market. When an inferior piece was downgraded to a lower category, the main defect was noted. The main defects noted were wanes, knots and compression wood.

Work at the EPO-VALC and EPB-VALC sites began in fall and winter 2001, whereas the work in DUCHESNAY and LAC JAUNE was carried out in fall and winter 2002.

Using the variables measured, the following variables were calculated for each stem: the merchantable volume of the logs $(\mathrm{MV})$, the usable volume of the logs (UV), the number of board feet (BD-FT), the dollar value of the lumber (VAL), and the tapering (TAP) of a 16 -foot section $(508 \mathrm{~cm})$ corresponding to the first two logs. For MV estimates, the diameter inside the bark at the log's thick and thin ends was used, whereas only the diameter at the thin end was used for UV.

\section{Statistical analyses}

The variables TL, ML, MV, UV, BD-FT, VAL and TAP measured or calculated for each stem were analyzed in accordance with a covariance analysis model (PROC MIXED, SAS/STAT ${ }^{\circledR}$, SAS Institute Inc. 1999). The covariables, DBH and $\mathrm{DBH}^{2}$, made it possible to take stem dimensions into account. The initial model included one site effect (three levels), one grade category effect (white spruce and three grade qualities for Norway spruce), their interaction, the covariables and the leading interactions between the covariables and the factors (site and grade category). The model was then simplified by excluding interactions including DBH that were not significant at the 5\% level. In order to comply with normality and homogeneity postulates of residual variance, the values of the dependent variables MV, UV and VAL were converted into their square root and that of BD-FT was converted into its logarithm. The variables TL, ML and TAP were not converted. Contrasts, defined $a$ priori, were established on the significant effects. Partial correlations were calculated on all of the measured or calculated dependent variables.

For the analysis of defects that led to the downgrading of 2 -in. lumber, namely the presence of wanes, knots or compression wood, each defect was analyzed using a generalized linear mixed model (PROC GENMOD, SAS/STAT $^{\circledR}$; SAS Institute Inc. 1999). The presence or absence of a defect constituted a presumed binomial response variable. For visual grading analysis, the lumber was grouped into two categories: Select Structural, No. 1 and No. 2 (S-1-2) or No. 3 and Economy (3-E). Whether the lumber belonged to category S-1-2 or not constituted the response variable. Effects including the DBH covariable were not taken into account if they were not significant at the $5 \%$ level. Contrasts, defined a priori, were established on significant effects.

Contrasts defined a priori for Norway spruce grade qualities were Q2 and Q3, representing stems with major deformations, which were compared with Q1. Q2 and Q3 were then compared with each other. For the sites, the defined contrasts were LAC JAUNE and DUCHESNAY, which were compared with EPO-VALC; LAC JAUNE was compared with DUCHESNAY and EPO-VALC was compared with EPBVALC.

\section{Results}

\section{Grade categories}

Grade categories assigned to Norway spruce stems have a very significant effect and lead to a reduction in TL, MV, UV, BDFT and VAL values on all sites (Tables 2 and 3 ). The more the stems are deformed, the more significant the negative impact is on these variables. Q1, representing stems without any major deformation, is clearly different from Q2 and Q3, which represent stems with one or more major deformations, respectively, for TL, MV, UV, BD-FT and VAL values (Tables 3 and 4). Where an individual stem is concerned, Q2 and Q3 present, in comparison with Q1, relative losses of $6.3 \%$ in total height, $14.7 \%$ in merchantable volume of the logs, $14.2 \%$ in usable volume, $20.6 \%$ in the number of board feet, and $23.7 \%$ in the lumber's dollar value (Table 4).

Likewise, Q2 is different from Q3, which represents stems with more than one major deformation, for all of the variables previously mentioned (Tables 3 and 4). Q3, in comparison with Q2, presents relative losses of $10.2 \%$ in TL, $15.0 \%$ in $\mathrm{MV}, 14.5 \%$ in UV, $13.9 \%$ in BD-FT and $18.9 \%$ in VAL (Table 4). When we compare Q3 with Q1, the losses are even more significant. The value of lumber for Q1 is $\$ 12.49$ whereas the value for $\mathrm{Q} 3$ is $\$ 8.54$, which represents an average relative loss between the two grade qualities of $32 \%$.

A difference between the plantation sites was also observed for TL, MV, UV, BD-FT and VAL (Table 2). This difference is mainly due to LAC JAUNE, which is clearly different from DUCHESNAY and EPO-VALC because of its lower values for these variables (Table 3 ).

There is no indication that TAP varies with grade category or following the presence or absence of major deformations caused by the weevil in Norway spruce (Table 2). However, a difference between the sites was observed, but the analysis of significant interactions reveals that this difference between sites is not the same depending on the grade category and on whether stems have a higher or lower DBH (Table 2).

Grade qualities have a significant effect on ML but this effect varies, as demonstrated by the presence of interactions, according to combinations of grade qualities and sites and depending on whether the DBH is larger or smaller (Table 2). However, aside from a few exceptions, such as Q2 at DUCHESNAY, ML is negatively affected by major deformations. Thus, for EPO-VALC, ML values of 11.1, 9.7 and $9.5 \mathrm{~m}$, for an average diameter of $17.5 \mathrm{~cm}$, were obtained for Q1, Q2 and Q3, respectively.

All of the variables, with the exception of TAP, are positively and strongly correlated $(p<0.0001)$. The variables that display the highest correlations are MV and UV $(r=$ 
Table 2. Probabilities associated with the analysis of variance for the total length of stems (TL), the merchantable volume of logs (MV), the usable volume of logs (UV), the number of board feet (BD-FT), the monetary value of lumber (VAL), the taper of the first two logs (TAP), and the merchantable length of the stem (ML) produced by trees in three grade categories in three plantations of Norway spruce and one plantation of white spruce.

\begin{tabular}{|c|c|c|c|c|c|c|c|c|}
\hline Source of Variation & $\mathrm{DF}^{\mathrm{b}}$ & $\mathrm{TL}$ & MV & UV & BD-FT & VAL & TAP & ML \\
\hline Grade category $^{\mathrm{a}}$ (QUA) & 3 & 0.0076 & $<0.0001$ & $<0.0001$ & $<0.0001$ & $<0.0001$ & 0.0663 & 0.0437 \\
\hline Site $(S)$ & 2 & $<0.0001$ & $<0.0001$ & $<0.0001$ & $<0.0001$ & $<0.0001$ & 0.0220 & 0.3802 \\
\hline $\mathrm{S} \times \mathrm{QUA}$ & $4^{\mathrm{c}}$ & 0.4444 & 0.3235 & 0.3262 & 0.6483 & 0.4549 & 0.0065 & 0.0430 \\
\hline $\mathrm{DBH}$ & 1 & $<0.0001$ & $<0.0001$ & $<0.0001$ & 0.0002 & $<0.0001$ & 0.4641 & 0.1637 \\
\hline $\mathrm{DBH} \times \mathrm{S}$ & 2 & - & - & - & - & - & 0.0551 & 0.3744 \\
\hline $\mathrm{DBH} \times \mathrm{QUA}$ & 3 & - & - & - & - & - & 0.1145 & 0.0541 \\
\hline $\mathrm{DBH} \times \mathrm{S} \times \mathrm{QUA}$ & $4^{\mathrm{c}}$ & - & - & - & - & - & 0.0063 & 0.0418 \\
\hline $\mathrm{DBH}^{2}$ & 1 & - & 0.0390 & - & 0.0301 & - & - & 0.2643 \\
\hline $\mathrm{DBH}^{2} \times$ Site & 2 & - & - & - & - & - & - & 0.3811 \\
\hline $\mathrm{DBH}^{2} \times \mathrm{QUA}$ & 3 & - & - & - & - & - & - & 0.0608 \\
\hline $\mathrm{DBH}^{2} \times \mathrm{S} \times \mathrm{QUA}$ & $4^{\mathrm{c}}$ & - & - & - & - & - & - & 0.0415 \\
\hline
\end{tabular}

a White spruce and three grade categories of Norway spruce were considered: Q1= Stem without major deformations; Q2 = Stem with only one major deformation on the merchantable part $(>9 \mathrm{~cm})$; Q3 $=$ Stem with more than one major deformation on the merchantable part.

begrees of freedom.

cFour DF instead of six because white spruce was not repeated at DUCHESNAY and LAC JAUNE.

$0.96)$, and BD-FT and VAL $(r=0.87)$. TAP is slightly and negatively correlated with $\mathrm{UV}(\mathrm{r}=-0.25 ; p=0.0010)$, BD-FT $(\mathrm{r}=-0.19 ; p=0.0123), \mathrm{VAL}(\mathrm{r}=-0.21 ; p=0.0046)$ and $\mathrm{ML}(\mathrm{r}$ $=-0.26 ; p=0.0005)$.

\section{Norway spruce vs. white spruce}

On the Valcartier site, stems originating from EPB-VALC are the same length as stems from EPO-VALC containing the three grade qualities (Tables 3 and 4). However, for the other variables, the results obtained for EPO-VALC are different (Table 4) and higher than those of EPB-VALC. More precisely, Norway spruce presents on average $12.46 \%$ more merchantable volume, $21.74 \%$ more usable volume, $20.86 \%$ more BD-FT and $26.74 \%$ more dollar value for the lumber than white spruce (Tables 3 and 4). For an average DBH of $17.51 \mathrm{~cm}$, the TAP for EPB-VALC is higher than that of EPOVALC ( 1.4 vs. $1.1 \mathrm{~cm} / \mathrm{m} ; p<0.0001)$, and the ML for EPBVALC is $6 \%$ smaller than that of EPO-VALC (9.54 vs. $10.1 \mathrm{~m}$; $p=0.0453)$.

\section{Lumber classification}

For Norway spruce, regardless of the grade category or the site, the presence of wanes led to similar proportions of downgrading, varying between $18 \%$ and $31 \%$ depending on grade qualities (Table 5) and between $22 \%$ and $26 \%$ depending on the site (Table 5). For the Valcartier site, downgrading caused by wanes in white spruce was higher than in Norway spruce, i.e., $32 \%$ vs. $22 \%$ (Table 5).

In the case of downgrading caused by knots, grade qualities did not have a significant effect (Table 5), but the sites caused significant variations (Table 5). Thus, a larger proportion of lumber originating from LAC JAUNE was downgraded for this defect compared with lumber from DUCHESNAY (37\% vs. $16 \%$; Table 5). The proportion of lumber downgraded was comparable to EPO-VALC and DUCHESNAY, i.e., $20 \%$ and $16 \%$, respectively. The relative risk that lumber originating from LAC JAUNE would be downgraded was 3.7 times higher than for lumber from
DUCHESNAY, and 2.6 times higher than for lumber from EPO-VALC. No difference was found for this variable between white spruce and Norway spruce at the Valcartier site (22\% vs. $20 \%$; Table 5 ).

The presence of compression wood, closely associated with minor and major deformations caused by the weevil and sufficiently present to lead to downgrading, was observed for all grade qualities and at all the sites. However, grade quality did not have an effect on the proportion observed (Table 5). The proportion of lumber having this defect was much higher at DUCHESNAY than at the two other sites (23\% vs. 10 and $7 \%$; Table 5). The risk that lumber originating from DUCHESNAY would be downgraded for this defect was 3.7 times higher than for EPO-VALC and 3.0 times higher than for LAC JAUNE. None of the white spruce lumber was downgraded due to the presence of compression wood.

The drying schedule used made it possible to produce lumber of very good overall quality. Very few defects associated with this operation, such as warps, were observed. Only 2\% of lumber originating from Norway spruce and 6\% from white spruce at Valcartier were downgraded by warps. No statistical analysis was made on this defect.

The analysis carried out on the grading of lumber grouped under two categories, i.e., S-1-2 and 3-E, did not reveal any differences between the grade qualities of the stems (Table 5). However, a difference between the sites was found (Table 5). The proportion of lumber graded as category 3-E was higher for LAC JAUNE than for EPO-VALC and DUCHESNAY (Table 5). The relative risk that lumber from LAC JAUNE would be graded as category 3-E was 2.5 times higher than for EPO-VALC and 3.0 times higher than for DUCHESNAY. White spruce also differed from Norway spruce (Table 5) at Valcartier because the risk that its lumber would be placed in category 3-E, the least valuable, was 3.8 times higher. At the better sites, i.e., DUCHESNAY and EPO-VALC, $74.4 \%$ and $73 \%$ of Norway spruce lumber was graded as category S-1-2, respectively, whereas only $54 \%$ of lumber was graded as category S-1-2 in LAC JAUNE (Table 6). White spruce, 
Table 3. Average estimates ${ }^{a}$ of total length (TL), merchantable volume of logs (MV), usable volume of logs (UV), number of board feet (BD-FT) and monetary value of lumber (VAL) based on three stem grades for three Norway spruce plantation sites, and for one plantation of Norway spruce (EPO-VALC) and one plantation of white spruce (EPB-VALC) on the Valcartier site only.

\begin{tabular}{|c|c|c|c|c|c|}
\hline Grade Category $^{\mathrm{b}}$ or Site & $\begin{array}{l}\mathrm{TL} \\
(\mathrm{m})\end{array}$ & $\begin{array}{l}\text { MV } \\
\left(\mathrm{dm}^{3}\right)\end{array}$ & $\begin{array}{l}\text { UV } \\
\left(\mathrm{dm}^{3}\right)\end{array}$ & $\begin{array}{l}\text { BD FT } \\
(\text { bd ft) }\end{array}$ & $\begin{array}{l}\text { VAL } \\
(\$)\end{array}$ \\
\hline \multicolumn{6}{|c|}{ For the three plantation sites } \\
\hline Q1 & $\begin{array}{l}14.2 \\
(0.36)^{\mathrm{c}}\end{array}$ & $\begin{array}{l}149.1 \\
(139.1 ; 159.5)^{\mathrm{d}}\end{array}$ & $\begin{array}{l}119.4 \\
(110.6 ; 128.6)\end{array}$ & $\begin{array}{l}32.92 \\
(30.22 ; 35.86)\end{array}$ & $\begin{array}{l}12.49 \\
(11.33 ; 13.71)\end{array}$ \\
\hline Q2 & $\begin{array}{l}14.1 \\
(0.33)\end{array}$ & $\begin{array}{l}137.5 \\
(128.7 ; 146.6)\end{array}$ & $\begin{array}{l}110.4 \\
(102.7 ; 118.5)\end{array}$ & $\begin{array}{l}28.10 \\
(26.00 ; 30.39)\end{array}$ & $\begin{array}{l}10.53 \\
(9.56 ; 11.54)\end{array}$ \\
\hline Q3 & $\begin{array}{l}12.6 \\
(0.37)\end{array}$ & $\begin{array}{l}117.0 \\
(107.9 ; 126.5)\end{array}$ & $\begin{array}{l}94.4 \\
(86.3 ; 102.7)\end{array}$ & $\begin{array}{l}24.19 \\
(22.16 ; 26.41)\end{array}$ & $\begin{array}{l}8.54 \\
(7.56 ; 9.57)\end{array}$ \\
\hline \multicolumn{6}{|c|}{ For the three grade categories } \\
\hline EPO-VALC & $\begin{array}{l}14.7 \\
(0.12)\end{array}$ & $\begin{array}{l}149.8 \\
(145.1 ; 154.7)\end{array}$ & $\begin{array}{l}123.2 \\
(119.0 ; 127.6)\end{array}$ & $\begin{array}{l}32.96 \\
(31.67 ; 34.30)\end{array}$ & $\begin{array}{l}12.75 \\
(12.20 ; 13.32)\end{array}$ \\
\hline DUCHESNAY & $\begin{array}{l}14.3 \\
(0.42)\end{array}$ & $\begin{array}{l}144.8 \\
(133.4 ; 156.7)\end{array}$ & $\begin{array}{l}116.8 \\
(106.7 ; 127.4)\end{array}$ & $\begin{array}{l}30.85 \\
(27.93 ; 34.06)\end{array}$ & $\begin{array}{l}11.59 \\
(10.30 ; 12.95)\end{array}$ \\
\hline LAC JAUNE & $\begin{array}{l}12.0 \\
(0.42)\end{array}$ & $\begin{array}{l}109.9 \\
(100.1 ; 120.1)\end{array}$ & $\begin{array}{l}85.4 \\
(76.9 ; 94.3)\end{array}$ & $\begin{array}{l}22.01 \\
(19.97 ; 24.28)\end{array}$ & $\begin{array}{l}7.43 \\
(6.42 ; 8.52)\end{array}$ \\
\hline \multicolumn{6}{|l|}{ For the Valcartier site only } \\
\hline Q1 & $\begin{array}{l}15.3 \\
(0.23)\end{array}$ & $\begin{array}{l}168.4 \\
(159.0 ; 178.2)\end{array}$ & $\begin{array}{l}138.5 \\
(130.1 ; 147.1)\end{array}$ & $\begin{array}{l}37.75 \\
(35.01 ; 40.70)\end{array}$ & $\begin{array}{l}14.41 \\
(13.31 ; 15.56)\end{array}$ \\
\hline Q2 & $\begin{array}{l}14.7 \\
(0.20)\end{array}$ & $\begin{array}{l}145.3 \\
(137.7 ; 153.2)\end{array}$ & $\begin{array}{l}119.3 \\
(112.5 ; 126.4)\end{array}$ & $\begin{array}{l}32.77 \\
(30.68 ; 35.00)\end{array}$ & $\begin{array}{l}12.65 \\
(11.75 ; 13.59)\end{array}$ \\
\hline Q3 & $\begin{array}{l}14.0 \\
(0.20)\end{array}$ & $\begin{array}{l}136.7 \\
(129.2 ; 144.3)\end{array}$ & $\begin{array}{l}112.6 \\
(106.0 ; 119.5)\end{array}$ & $\begin{array}{l}28.94 \\
(27.09 ; 30.92)\end{array}$ & $\begin{array}{l}11.29 \\
(10.44 ; 12.18)\end{array}$ \\
\hline Q1. Q2 and Q3 ${ }^{\mathrm{e}}$ & $\begin{array}{l}14.7 \\
(0.12)\end{array}$ & $\begin{array}{l}149.8 \\
(145.1 ; 154.7)\end{array}$ & $\begin{array}{l}123.2 \\
(119.0 ; 127.6)\end{array}$ & $\begin{array}{l}32.96 \\
(31.67 ; 34.30)\end{array}$ & $\begin{array}{l}12.75 \\
(12.20 ; 13.32)\end{array}$ \\
\hline EPB-VALC & $\begin{array}{l}14.3 \\
(0.21)\end{array}$ & $\begin{array}{l}133.2 \\
(125.7 ; 141.0)\end{array}$ & $\begin{array}{l}101.2 \\
(94.7 ; 107.8)\end{array}$ & $\begin{array}{l}27.27 \\
(25.48 ; 29.18)\end{array}$ & $\begin{array}{l}10.06 \\
(9.23 ; 10.92)\end{array}$ \\
\hline
\end{tabular}

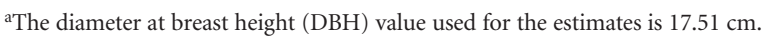

${ }^{b}$ White spruce and three grade categories of Norway spruce were considered: Q1= Stem without major deformations; Q2 = Stem with only one major deformation on the merchantable part $(>9 \mathrm{~cm})$; Q3 $=$ Stem with more than one major deformation on the merchantable part.

'Standard error.

${ }^{\mathrm{d}}$ Lower bound; upper bound of a confidence interval of 95\%.

'Idem at EPO-VALC.

despite a height growth similar to that of DUCHESNAY and EPO-VALC, had $63.2 \%$ of its lumber graded as S-1-2 (Table 6).

\section{Discussion}

\section{Effect of the weevil on productivity}

The results of this study clearly demonstrate that major deformations caused by the white pine weevil on Norway spruce have significant negative effects on the height of trees, volume production and other correlated variables, such as the number of board feet and the lumber's dollar value. However, when we spread out these negative effects over an entire plantation, they decrease in significance. For example, at the time of the second thinning, Valcartier's Norway spruce plantation included 34\% Q1 stems, 43\% Q2 stems and 24\% Q3 stems. By using these proportions and the average losses observed (Q1 vs. Q2 and Q3; Table 4) and comparing this productivity with the productivity obtained from a plantation made up of $100 \%$ Q1 stems, it is possible to estimate losses for the Valcartier plantation. Thus, at the time of the second thinning, the Valcartier plantation's losses in comparison with tree losses were $10.4 \%$ instead of $14.7 \%$ for merchantable volume, $11.3 \%$ instead of $20.6 \%$ for the 
Table 4. Thresholds observed in the contrasts obtained between stem grades for total length (TL), merchantable volume of logs (MV), usable volume of logs (UV), number of board feet (BD-FT), monetary value of lumber (VAL), and losses or relative gains in $\%$ based on three stem grade categories for three Norway spruce plantation sites, and for one plantation of Norway spruce (EPO-VALC) and one plantation of white spruce (EPB-VALC) on the Valcartier site only.

\begin{tabular}{|c|c|c|c|c|c|}
\hline Contrast & $\mathrm{TL}$ & MV & UV & BD-FT & VAL \\
\hline \multicolumn{6}{|l|}{ For the three plantation sites } \\
\hline Q2 and Q3 vs Q1 & $\begin{array}{l}0.0402 \\
-6.3 \%\end{array}$ & $\begin{array}{l}0.0004 \\
-14.7 \%\end{array}$ & $\begin{array}{l}0.0016 \\
-14.2 \%\end{array}$ & $\begin{array}{l}<0.0001 \\
-20.6 \%\end{array}$ & $\begin{array}{l}<0.0001 \\
-23.7 \%\end{array}$ \\
\hline Q3 vs Q2 & $\begin{array}{l}0.0037 \\
-10.2 \%\end{array}$ & $\begin{array}{l}0.0019 \\
-15.0 \%\end{array}$ & $\begin{array}{l}0.0058 \\
-14.5 \%\end{array}$ & $\begin{array}{l}0.0118 \\
-13.9 \%\end{array}$ & $\begin{array}{l}0.0061 \\
-18.9 \%\end{array}$ \\
\hline \multicolumn{6}{|l|}{ For the Valcartier site } \\
\hline EPO-VALC vs EPB-VALC & 0.0895 & $\begin{array}{l}0.0004 \\
+12.5 \%\end{array}$ & $\begin{array}{l}<0.0001 \\
+21.7 \%\end{array}$ & $\begin{array}{l}<0.0001 \\
+20.9 \%\end{array}$ & $\begin{array}{l}<0.0001 \\
+26.7 \%\end{array}$ \\
\hline
\end{tabular}

White spruce and three grade categories of Norway spruce were considered: Q1= Stem without major deformations; Q2 = Stem with only one major deformation on the merchantable part $(>9 \mathrm{~cm})$; Q3 = Stem with more than one major deformation on the merchantable part.

Table 5. Probabilities associated with the analysis of variance in the proportion of lumber exhibiting a defect (wanes, knots or compression wood) resulting in its downgrading and in the proportion of lumber broken down into two visual grading categories (S-1-2 or 3-E) from trees in three grade categories in three plantations of Norway spruce and one plantation of white spruce (EPB-VALC), and the thresholds observed in the contrasts between the sites.

\begin{tabular}{|c|c|c|c|c|c|}
\hline Source of Variation & $\mathrm{DF}^{\mathrm{b}}$ & Wanes & Knots & $\begin{array}{l}\text { Compression } \\
\text { Wood }^{c}\end{array}$ & $\begin{array}{l}\text { Visual } \\
\text { Grading }\end{array}$ \\
\hline Grade category $^{\mathrm{a}}$ (QUA) & 3 & 0.1445 & 0.0875 & 0.7702 & 0.0667 \\
\hline Site $(S)$ & 2 & 0.8211 & 0.0009 & 0.0004 & 0.0056 \\
\hline $\mathrm{S} \times \mathrm{QUA}$ & $4^{\mathrm{d}}$ & 0.8215 & 0.0628 & 0.3113 & 0.3651 \\
\hline \multicolumn{6}{|l|}{ Contrasts } \\
\hline DUCHESNAY vs LAC JAUNE & & 0.6346 & 0.0014 & 0.0243 & 0.0090 \\
\hline LAC JAUNE vs EPO-VALC & & 0.5266 & 0.0003 & 0.6235 & 0.0016 \\
\hline DUCHESNAY vs EPO-VALC & & 0.9984 & 0.3140 & $<0.0001$ & 0.5792 \\
\hline EPO-VALC vs EPB-VALC & & 0.0143 & 0.5026 & - & 0.0341 \\
\hline
\end{tabular}

aWhite spruce and three grade categories of Norway spruce were considered: Q1= Stem without major deformations; Q2 = Stem with only one major deformation on the merchantable part $(>9 \mathrm{~cm})$; Q3 = Stem with more than one major deformation on the merchantable part.

${ }^{b}$ Degrees of freedom.

${ }^{c}$ For this variable, the DF is two instead of three for QUA because white spruce without defects associated with the presence of compression wood was not included in the analysis.

${ }^{\mathrm{d}}$ Four DF instead of six because white spruce was not repeated at DUCHESNAY and LAC JAUNE.

Table 6. Breakdown of 2-inch-thick lumber by NGLA grade and by two visual grading categories (S-1-2 and 3-E) for the three Norway spruce sites (three grade categories included) and the white spruce site at Valcartier (EPB-VALC).

\begin{tabular}{|c|c|c|c|c|c|c|c|c|}
\hline Sites & $\begin{array}{l}\text { Number of } \\
\text { lumber pieces }\end{array}$ & $S$ & 1 & 2 & $S-1-2$ & 3 & $\mathrm{E}$ & $3-E$ \\
\hline LAC JAUNE & 87 & $10.3 \%$ & $4.6 \%$ & $39.1 \%$ & $54.0 \%$ & $18.4 \%$ & $27.6 \%$ & $46.0 \%$ \\
\hline DUCHESNAY & 86 & $25.6 \%$ & $10.5 \%$ & $38.3 \%$ & $74.4 \%$ & $4.6 \%$ & $21.0 \%$ & $25.6 \%$ \\
\hline EPO-VALC & 586 & $18.1 \%$ & $40.6 \%$ & $14.3 \%$ & $73.0 \%$ & $10.6 \%$ & $16.4 \%$ & $27.0 \%$ \\
\hline EPB-VALC & 182 & $14.8 \%$ & $36.3 \%$ & $12.1 \%$ & $63.2 \%$ & $11.0 \%$ & $25.8 \%$ & $36.8 \%$ \\
\hline
\end{tabular}


number of board feet, and $10.4 \%$ instead of $23.77 \%$ for dollar value losses. In addition, even if the losses still seem rather high with regard to the number of board feet and the lumber's dollar value, one must consider that a portion of the volume will be recovered during chip processing or for the production, in certain mills, of lumber shorter than 8 feet. Therefore, the most representative loss at this stage is that which is assessed by the loss in merchantable volume.

During the assessment of losses at the plantation level, the use of Q1 as the reference point seems to be the best option, but it remains debatable as it could lead to a slight underestimation. In fact, the majority of the stems graded Q1 had already suffered weevil attacks. Even if they did not lead to major deformations, they most certainly affected the height of the stems and, consequently, merchantable volume. However, according to Lavallée et al. (1990), the weevil does not only attack the highest stems but all height classes in proportion to the number of stems per height category. For the tests of Valcartier sources used in this study, Daoust (1996) determined that the weevil had caused a height reduction of only $1 \%$ after 30 years in crop trees that were affected by the weevil in comparison with those that showed no evidence on the trunks. For a six-year growth phase, following light attack simulations in a clonal test on Norway spruce, Daoust (unpublished data) observed an average reduction in height growth of $15 \%$. However, this reduction represented no more than $5 \%$ of the total height of the clones studied (5.5 m on average). For white pine, Morrow (1965) assumed that a minimum of $60 \%$ to $70 \%$ of annual growth would be lost during an attack. Brace (1971) determined that pines having suffered a dozen attacks or so before harvesting would possibly be up to $3 \mathrm{~m}$ shorter and that their total volume could diminish by $3 \%$ to $20 \%$. Considering the ability of Norway spruce to regenerate its leader from side or adventitious buds all along the main stem, we do not believe that the impact is as severe as that observed in white pine. Consequently, we can consider that the estimate of merchantable volume loss caused by the weevil at the time of a second thinning is biased by an underestimation of the average height of Q1 trees and that it should be higher than the $10.4 \%$ previously estimated, i.e., a possible loss in merchantable volume of $12 \%$ to $15 \%$.

Now that the loss due to major deformations at the time of a second thinning has been estimated, we must look at it on a broader horizon and consider the complete rotation of a plantation and its thinning schedule. If we take the example of the Valcartier plantation and examine the merchantable volume harvested and to be harvested in future years, we realize that the proportion of the volume harvested during this second thinning represents only $16 \%$ of the plantation's total production, namely 112 of the $700 \mathrm{~m}^{3} /$ ha expected at 65 years (Fig. 3). The loss of $12 \%$ to $15 \%$ therefore applies to the production of the second thinning and represents a relative loss of only $1.9 \%$ to $2.4 \%(12-15 \%$ of $16 \%)$ of the total production of the plantation. In addition, the first two selective thinnings, where $73 \%$ of the trees most affected and deformed by the weevil were harvested, would have allowed the final crop to improve and minimize future losses. In addition, for the first three logs totalling 24 feet $(762 \mathrm{~cm})$ in length, or approximately half of the total height of the stems, the average proportion of merchantable volume harvested reached $94 \%$ in each tree cut for the study at the time of the second thinning at Valcartier. Therefore, if this relationship holds, it is entirely plausible that the majority of the future volume will come from the bottom of residual trees and that its quality will improve (de Groot et al. 2005). Selective thinnings previously carried out will promote an increase in DBH in residual trees (Prégent 2003, Mäkinen and Isomäki 2004). Several mature white pines presented internal signs of weevil attacks, but there was no major deformation visible on their trunks (de Groot et al. 2005). In white pine plantations in Wisconsin that suffered weevil attacks, Pubanz et al. (1999) assessed the average volume deduction in the first 5-m log at only $1.3 \%$ for crop trees with an average DBH of $23 \mathrm{~cm}$.

Our general estimate claiming relatively low volume losses in the total production of the Valcartier plantation reflects the conclusions of Prégent (1998). In fact, he pointed out that even if the plantations are affected by disruptive elements such as the weevil, with a rate of severely affected stems of $30 \%$ to $40 \%$ and relatively even damage distribution, there are enough stems left after the first thinning to obtain excellent total production. Thus, the fears raised by MacArthur (1964) and Holst (1955) to the effect that wood of lumber quality could not be produced on Norway spruce plantations severely affected by the weevil are vanishing. Economic losses will be well below the $25 \%$ average estimate by Brace (1971) for white pine or the maximum of $40 \%$ calculated by Marty and Mott (1964) for northeastern American white pine stands ravaged by the weevil. Economic losses caused to Norway spruce by the white pine weevil are less severe than those caused to white pine, especially because of the much higher price range offered for quality white pine lumber. The most significant loss in white pine is not the loss in volume but rather the deterioration in quality of the logs for lumber (Szuba and Pinto 1991). Damage caused by red rot (Fomes pini [Thore] Lloyd) following weevil attacks on white pine is significant (Ostrander and Foster 1957, Brace 1971).

In our study, there was no sign of rot observed on Norway spruce lumber following weevil attacks. One must also consider that for Norway spruce, as for other species in the fir-pine-spruce category, all coarse lumber residues are directed to and used by the pulp and paper industry. In addition, in the context of forestry operations on logs of multiple lengths $(8,10,12$ and 16 feet), a better cross-cutting of logs in relation to major deformations could contribute to an even greater decrease in merchantable volume losses as compared with a fixed operation of 8 -foot logs, such as we used for this study.

For the variables TAP and ML, the study did not enable us to confirm that the major deformations caused by the weevil had a direct effect on these variables. This is not surprising in the case of TAP as this variable was observed on a 16-foot section representing the first two logs. Virtually no major deformation was present in this portion of the trees, which is a direct effect of the first selective thinning on the quality of the trunks of residual trees. The site and derived factors (spacing and thinning schedule) seemed to have a much more significant effect on this variable than grade category. For ML, a higher number of sample trees from DUCHESNAY and LAC JAUNE might have made it possible to avoid significant interactions and to demonstrate the tendency observed for all grade categories and all $\mathrm{DBH}$, namely the 


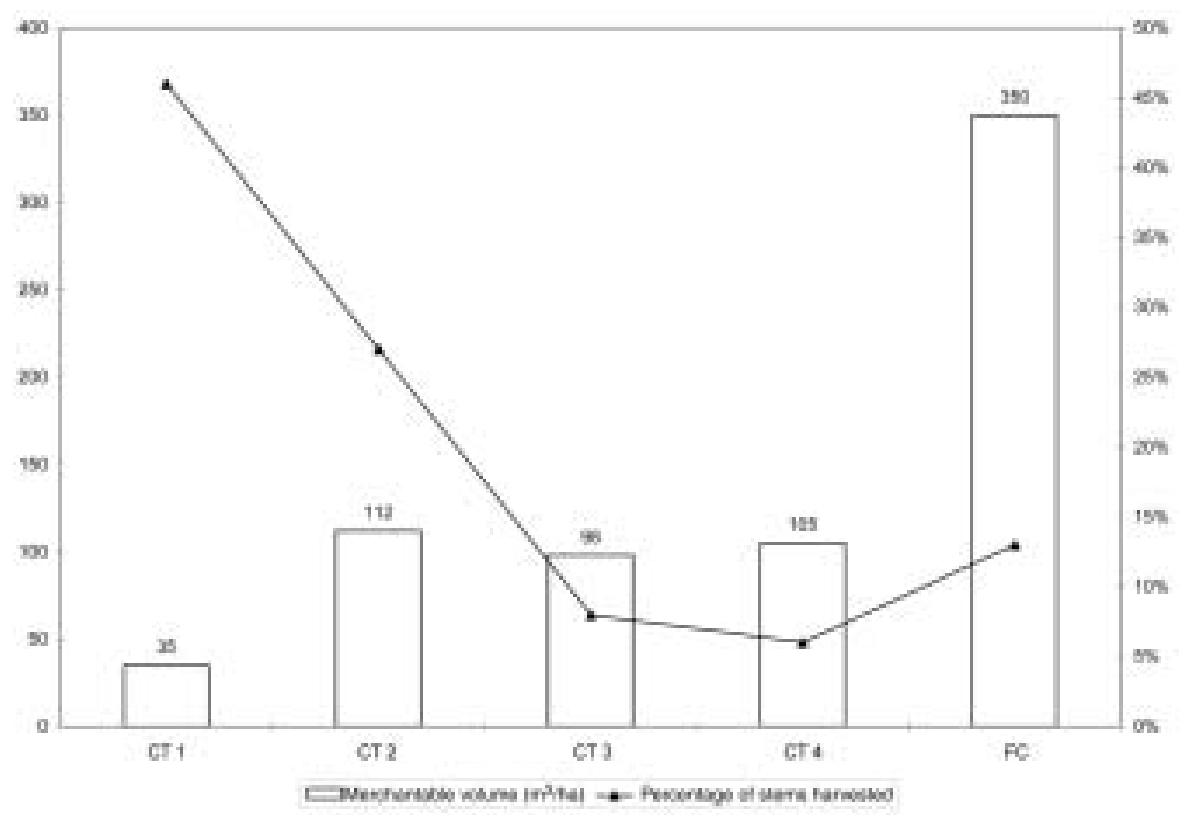

Fig. 3. Percentage of harvested stems and merchantable volume produced in the Valcartier Norway spruce plantation based on a scenario of four commercial thinnings (CT 1 to 4) and a final cut (FC). The values for CT 1 and CT 2 are based on actual data, whereas the data for the other treatments are estimates from Prégent (1998) and Bolghari and Bertrand (1984).

effect of grade category on this variable. At the Valcartier site, where close to 40 stems were sampled by grade category, the effect of grade category was evident, thus demonstrating that the presence of major deformations $(\mathrm{Q} 2$ and $\mathrm{Q} 3)$ reduces $\mathrm{ML}$ by approximately $13 \%$ in comparison with Q1.

\section{Effect of the weevil on lumber quality}

The presence or absence of major deformations caused by the weevil did not have an impact on the presence of defects such as wanes, knots and compression wood, which could have negatively affected the visual grading of the lumber. Therefore, whether the stems were deformed or not, the quality of the lumber was similar. However, there is no doubt that weevil attacks, whether they caused minor or major deformations (Fig. 2), led to the formation of compression wood in stems. However, the impact on lumber grading caused by compression wood brought about by major deformations is very low as these deformations were taken into account and eliminated for the most part at the time of cross-cutting. The largest proportion of downgrading due to compression wood was observed at DUCHESNAY. This difference compared with the two other sites is difficult to explain. According to our observations, minor deformations were not more frequent at DUCHESNAY than at the two other sites; therefore, we cannot attribute the larger proportion of downgrading to this factor. We believe that it rather could have been amplified by the smaller frequency of other defects, such as wanes and knots. As these are more rapidly identified and that only the main defect causing downgrading was noted, this could explain that in the absence of finding wanes and knots, the grader had to look for less evident defects, such as compression wood. However, in spite of this, this defect presents limited consequences since almost $75 \%$ of the lumber from this site was graded as Category S-1-2 (Table 6). The presence of compression wood was not observed in white pine lumber, a species hardly affected by the weevil.

Despite the more difficult drying conditions caused by a delay between lumber operations and the availability of the dryer and a long-term stay at the mill, the results observed for this lumber were better than the average observed in the softwood industry and present future prospects for this industry (P. Asselin, Tecseb Ltd., personal communication).

\section{Differences between sites}

Irrespective of the grade categories, the differences noted between sites are not surprising as the initial spacing and the intensity of thinnings influence the shape, the DBH and stem characteristics (knot size, living crown length) (Prégent 1998, 2003; Mäkinen and Isomäki 2004). It is therefore not surprising to observe that the LAC JAUNE stems, which have in addition a lower average height than the two other sites, present a lower value for all of the productivity variables studied. Also, LAC JAUNE lumber is characterized by a greater occurrence of knots, which leads to a greater proportion of downgrading, which was reflected by a larger proportion of lumber in the 3-E category. These findings are linked in particular to the initial spacing of $2.4 \times 2.4 \mathrm{~m}$, which favoured a high proportion of green crowns (Table 1) and the growth of large branches in comparison with the other sites, where the trees were planted at $1.8 \times 1.8 \mathrm{~m}$ spacing. In a similar study conducted in plantations of 
Norway spruce in New Brunswick, Chui (1995) observed the same down-grading effect due to large spacing $(2.4 \times 2.4 \mathrm{~m})$ and the presence of larger branches and, therefore, larger knots. The impact of these larger knots is an important factor to take into account as in addition to affecting visual grading, this can also lead to a decrease in the mechanical properties of the wood (Chui 1995, Danborg 1996). For jack pine, Tong and Zhang (2005) observed that the increase in initial spacing had a positive effect on diameter growth, the width development of the crown and the size of knots, and that it caused a decrease in the quality of lumber. The increase in spacing in black spruce plantations and the resulting negative impacts on the quality of stems and of the wood were also observed by Zhang et al. (2002). The DUCHESNAY and EPO-VALC sites made it possible to produce, in spite of a rather high level of attacks, close to $75 \%$ of grade S-1-2 lumber. This result is comparable with those of Chui (1995) for plantations of similar age and spacing $(1.8 \times 1.8 \mathrm{~m})$, where the presence of the weevil was not mentioned.

\section{Norway spruce vs. white spruce at Valcartier}

Despite the negative impact of the weevil on Norway spruce at Valcartier, it is surprising to note that in the context of this study (i.e., for $\mathrm{DBH}$ categories of $14 \mathrm{~cm}$ to $23 \mathrm{~cm}$ ), the productivity obtained in merchantable and usable volume was higher than in white spruce, despite the fact that there was no difference in average height and that these two plantations were subject to similar management scenarios (spacing, thinning and pruning). In addition, the quantity and grading of Norway spruce lumber was higher, thus resulting in a higher dollar value. The factors that explain these results are mainly a higher ML, a higher UV/MV relationship, and a less pronounced TAP in Norway spruce. A more pronounced TAP in white spruce caused a greater presence of wanes in the lumber, which led to downgrading and, accordingly, to a lesser dollar value. The negative correlations observed in this study between TAP and the other variables such as UV, BD-FT, VAL and ML support this assertion. On average, when the two plantations located in Valcartier are compared, Norway spruce presents lumber with a $26 \%$ higher dollar value compared with white spruce for stems collected at the time of the second thinning. However, this point-in-time comparison does not allow us to apply these results to the total production of the two plantations or to generalize this result to all plantations of these two species without carrying out a much more extensive and comprehensive study.

\section{Conclusion}

Despite white pine weevil attacks and their negative impact, Norway spruce planted on sites with average to very good site quality indexes maintains a significant potential for productivity, both in quantity and quality, for wood collected during the second thinning. The negative impact should gradually decrease over the course of future thinnings and at the time of the final harvest.

\section{Acknowledgements}

The authors sincerely thank René Pâquet, Daniel Plourde and Jean-Paul Bilodeau, from the forest genetics team of the Canadian Forest Service (CFS), and Johanne Claveau, from the forestry research branch of the ministère des Ressources naturelles et de la Faune du Québec, for project execution and the gathering of data in the field and at the Duchesnay sawmill. We also thank, from the Policy and Liaison Directorate of the CFS, Claude Aerni for his advice and support in the achievement of this study, and Benoit Arsenault and Isabelle Lamarre for their editing work. We thank Daniel Filion and his team from l'École de foresterie et de technologie du bois de Duchesnay for operations at the sawmill and Pierre Asselin from Tecseb Ltd. for the monitoring of wood drying operations at Duchesnay. We also extend sincere thanks for the significant contribution made by Michèle Bernier-Cardou (CFS) and her team, comprised of Michèle Grenier, Maxime Boucher and Sylvain Boisclair, for the formulation of the experimental design and their continued work in statistical analyses.

\section{References}

Alfaro, R.I. 1989. Stem defects in Sitka spruce induced by Sitka spruce weevil, Pissodes strobi (Peck.). In R.I. Alfaro and S.G. Glover (eds.). Proc. of a Meeting of the IUFRO Working Group on Insects Affecting Reforestation: Biology and Damage, held under the auspices of the XVIII International Congress of Entomology, Vancouver, British Columbia, Canada, 3-9 July 1988. pp. 177-185. For. Can., Victoria, BC.

Archambault, L., J. Morissette, R. Lavallée and B. Comtois. 1993. Susceptibility of Norway spruce plantations to white pine weevil attacks in southern Quebec. Can. J. For. Res. 23: 2362-2369.

Ashman, R.I. 1962. Forest plantations in Maine. USDA For. Serv., Maine Agric. Exp. Stn., Bulletin 601. Maine, USA. 56 p.

Baldwin, H.I., J.E. Everett and D.E. Carlson. 1973. IUFRO Norway spruce provenance tests in New Hampshire and New York. Silvae Genet. 22(4): 93-114.

Beaulieu, J. 1996. Programme et stratégie d'amélioration génétique de l'épinette blanche au Québec. Ressour. nat. Can., Serv. can. for., Cent. for. Laurentides, Sainte-Foy, Québec. Rapp. inf. LAU-X-117. 26 p.

Bernier, L., P. Gagné, N. Feau, M.-J. Mottet, P. Périnet and R.C. Hamelin. 2003. L'établissement et la protection des plantations. In Actes des Colloques du Carrefour de la recherche forestière, 19 février 2003, Québec. pp. 33-40.

Bolghari, H.A. and V. Bertrand. 1984. Tables préliminaires de production des principales essences résineuses plantées dans la partie centrale du sud du Québec. Minist. Énergie Ressour. Québec, Serv. rech., Mém. n 79.392 p.

Boulet, B., G. Daoust, A. Stipanicic, É. Aubin, J. Claveau and R. Pâquet, 1997. Le charançon du pin blanc et de l'épinette de Norvège : plus de peur que de mal! Texte de conférence et affiche présentée au Carrefour de la recherche forestière, 18-19 février 1997. Ressour. nat. Québec, Dir. conserv. for., Ressour. nat. Can., Serv. can. for., Région du Québec, Sainte-Foy, Québec. 16 p.

Brace, L.G. 1971. Effects of white pine weevil damage on tree height, volume, lumber recovery and lumber value in eastern white pine. Petawawa For. Exp. Stn., Can. For. Serv., Dept. Environ., Publ. No. 1303. Petawawa, Ontario.

Chui, Y.H. 1995. Grade yields and wood properties of Norway spruce (Picea abies [L.] Karst.) from the Maritimes. For. Chron. 71(4): 473-478.

Comité d'amélioration génétique des arbres forestiers du Québec (CAGAFQ). 1983. Amélioration génétique des essences résineuses au Québec : Recherche et développement. A. Corriveau and G. Vallée (eds.). Environ. Can., Serv. can. for., Min. Énergie Ressour. Québec, Serv. rech. Sainte-Foy, Québec. 70 p.

Cornellier, P. 1995. Position du ministère des Ressources naturelles du Québec concernant le problème du charançon du pin blanc. In R. Lavallée and G. Bonneau (eds.). Compte rendu du Colloque sur le charançon du pin blanc. Sainte-Foy, Québec, 27-28 septembre 1994. pp. 111-117. Ressour. nat. Can., Serv. can. for., Région du Québec, Ressour. nat. Québec, Dir. rech. for., Sainte-Foy, Québec. 
Daoust, G. 1996. Épinette de Norvège : 2, Charançon du pin blanc : 1. L'Aubelle 112: 12-14.

Danborg, F. 1996. Juvenile wood in Norway and Sitka spruce. Anatomy, density, drying properties, visual grading and strength properties. Forskingsserien nr. 18-1996, Danish Forest and Landscape Research Institute, Hørsholm, Denmark.

de Groot, P., A.A. Hopkin and R.J. Sajan. 2005. Silvicultural techniques and guidelines for the management of major insects and diseases of spruce, pine and aspen in Eastern Canada. Nat. Resour. Can., Can. For. Serv., Great Lakes For. Cent., Sault Ste. Marie, Ontario. 65 p.

Holst, M.J. 1955. Breeding for weevil resistance in Norway spruce. Z. Forstgenet 4(2): 33-37.

Lavallée, R., C. Guertin, J. Morrissette and B. Comtois. 1990. Observations sur le développement du charançon du pin blanc chez l'épinette de Norvège au Québec. Revue d'entomologie du Québec, Vol. 35, nos 1 et $2: 31-44$.

MacArthur, J.D. 1964. Norway spruce plantations in Quebec. Can. Dept. For., Res. Branch Publ. 1059. 44 p.

Mäkinen, H. and A. Isomäki. 2004. Thinning intensity and growth of Norway spruce stands in Finland. Forestry 77: 349-364.

Marty, R. and D.G. Mott. 1964. Evaluating and scheduling white pine weevil control in the Northeast. USDA For. Serv., NE For. Exp. Stn, Upper Darby, PA, Res. Pap. NE-19.

Morrow, R.R. 1965. Height loss from white pine weevil. J. For. 63: 201-203.

NLGA. 1996. Règles de classification pour le bois d'oeuvre canadien. Commission nationale de classification des sciages, Burnaby, British Columbia. 268 p.
Ostrander, M.D. and C.H. Foster. 1957. Weevil-red rot associations in eastern white pine. U.S. For. Serv., Northeast. For. Exp. Stn., For. Res. Note 68.

Pratt, G.H. and C.H.C. Turner. 1986. Timber drying manual. $2^{\text {nd }}$ ed. Building Research Establishment Rep. Dept Environ., England. 152 p. Prégent, G. 1998. L'éclaircie des plantations. Gouv. du Québec, Minist. Ressour. nat., Forêt Québec, Dir. rech. for. Mém. rech. for. $\mathrm{n}^{\circ}$ 133. 38 p.

Prégent, G. 2003. Caractéristiques des arbres coupés et du peuplement résiduel à la première éclaircie commerciale de plantations résineuses. Minist. Ressour. nat., Faune et Parcs du Québec, Dir. rech. for. Mém. rech. for. $\mathrm{n}^{\circ} 143.54$ p.

Pubanz, D.M., R.L. Williams, D.L. Congos and M. Pecore. 1999. Effects of the white pine weevil in well-stocked eastern white pine in Wisconsin. North. J. Appl. For. 16: 185-190.

SAS Institute Inc. 1999. SAS/STAT User's Guide, Version 8, SAS Institute Inc., Cary, NC. 3884 p.

Szuba, K. and F. Pinto. 1991. Natural history of the white pine weevil and strategies to decrease its damage to conifers in Ontario. Central Ontario For. Tech. Develop. Unit. Tech. Rep. \#13.60 p.

Thiffault, N., V. Roy, G. Prégent, G. Cyr, R. Jobidon and J. Ménétrier. 2003. La sylviculture des plantations résineuses au Québec. Nat. Can. 127: 63-80.

Tong, Q.J. and S.Y. Zhang. 2005. Impact of initial spacing and precommercial thinning on jack pine tree growth and stem quality. For. Chron. 81(3): 418-428.

Zhang, S.Y., G. Chauret, H.Q. Ren and R. Desjardins. 2002. Impact of initial spacing on plantation black spruce lumber grade yield, bending properties, and MSR yield. Wood Fiber Sci. 34(3): 460-475. 